\title{
DISKUSI TENTANG PERAN POTENSI LOKAL DALAM PEMANFAATAN KOMODITAS DESA TELEMUNG KABUPATEN BANYUWANGI
}

\author{
Kustini Kustini ${ }^{1}$, Alfiandi Imam Mawardi ${ }^{2}$ \\ ${ }^{1}$ UPN Veteran Jawa Timur. Email: kustini259@gmail.com \\ 2UPN Veteran Jawa Timur. Email: alfiandi.ma@upnjatim.ac.id
}

\begin{abstract}
Telemung Village, Kalipuro Subdistrict, Banyuwangi Regency has several communities that can be utilized and maximized. In an effort to maximize this potential it is necessary to hold discussions to bring up new ideas and solutions to existing local potentials. The first thing to do is to map out existing problems and local potential through a Focus Group Discussion. The results of the discussion or Focus Group Discussion produced several solutions to help the community groups in Telemung village to increase their income from the resulting community. Local potential in the form of commodities will be better produced in the form of products than in the form of raw products. On the other hand, the use of various digital media is very important to encourage product branding. This will encourage the growth and development of local products in Telemung village to have maximum value added. The purpose of this activity is to find ideas and solutions to problems regarding the use of existing communities in the village of Telemung which are expected to improve the community's economy and increase knowledge of the community about their local potential. This activity will also encourage local potential to become a superior product for Banyuwangi district.
\end{abstract}

Keywords: Focus Group Discussion, Local Potential, Commodity and Value Added

\begin{abstract}
ABSTRAK
Desa Telemung kecamatan Kalipuro Kabupaten Banyuwangi memiliki beberapa komuditas yang dapat dimanfaatkan dan dimaksimalkan. Dalam usaha untuk maksimalkan potensi tersebut perlu diadakannya diskusi untuk memunculkan ide dan solusi baru terhadap potensi lokal yang ada. Hal awal yang harus dilakukan adalah melakukan mapping terhadap masalah dan potensi lokal yang ada melalui Focus Group Discussion. Hasil dari diskusi atau Focus Group Discussion menghasilkan beberapa solusi untuk membantu para kelompok masyarakat desa Telemung untuk menambah pendapatan mereka dari komuditas yang dihasilkan. Potensi lokal yang berupa komuditas akan lebih baik dihasilkan dalam bentuk produk dibandingkan berupa produk mentah. Di sisi lain, pemanfaatan berbagai media digital sangatlah penting untuk mendorong branding suatu produk. Hal inilah yang akan mendorong pertumbuhan dan perkembangan produk lokal desa Telemung hingga mempunyai value added yang maksimal. Tujuan kegiatan ini adalah untuk menemukan ide dan solusi dari permasalahan tentang pemanfaatan komuditas yang ada pada desa Telemung yang diharapan dapat meningkatkan ekonomi masyarakat dan menambah khasanah ilmu kepada masyarakat tentang potensi lokal yang mereka miliki. Kegiatan ini juga akan mendorong potensi lokal dapat menjadi produk unggulan bagi kabupaten Banyuwangi.
\end{abstract}

Kata Kunci: Focus Group Discussion, Potensi Lokal, Komuditas dan Value Added

\section{PENDAHULUAN}

Desa Telemung adalah sebuah desa di Kabupaten Banyuwangi yang berada di wilayah bagian utara, tepatnya kurang lebih $14 \mathrm{KM}$ dari Pusat Pemerintahan Kabupaten Banyuwangi ke arah Utara jalur menuju ke Kecamatan Kalipuro. Secara administratif Desa Telemung Kecamatan Kalipuro Kabupaten Banyuwangi masuk wilayah Kecamatan 
Kalipuro, dengan batas-batas sebagai berikut; bagian Utara berbatasan dengan Kelurahan Gombengsari, bagian Timur berbatasan dengan Desa Kelir, bagian Selatan berbatasan dengan Desa Bulusari dan bagian Barat berbatasan Hutan.

Dengan luas wilayah 572.100 Ha, Desa Telemung Kecamatan Kalipuro Kabupaten Banyuwangi merupakan desa yang tidak terlalu cukup luas wilayahnya di Kabupaten Banyuwangi. Dari luas wilayah tersebut terbagi menjadi beberapa bagian yaitu: 5,28\% berupa jalan, 30,20\% berupa pemukimam penduduk, 53,61\% berupa area Kebun, 10,66\% berupa area Hutan dan 0, 25\% berupa tempat dan tempat olahraga.

Topografi Desa Telemung Kecamatan Kalipuro Kabupaten Banyuwangi berupa dataran tinggi atau berada $15 \mathrm{KM}$ dari pantai. Sedangkan ketinggian rata-rata dari permukaan air laut $\pm 30 \mathrm{~m} \mathrm{dpl}$, dengan keadaan suhu rata-rata berkisar $26-30{ }^{\circ} \mathrm{C}$. Curah hujan rata-rata tiap tahun berkisar $2088 \mathrm{~mm}$, dengan demikian kondisi alam Desa Telemung Kecamatan Kalipuro Kabupaten Banyuwangi adalah daerah cukup subur dengan sumber air yang cukup dengan sedikit kesulitan dalam penyalurannya karena adanya permasalahan pipa air (http://telemung.desa.id/web/detailnews/kondisi-desa).

Desa Telemung, Kecamatan Kalipuro, Kabupaten Banyuwangi dikenal sebagai tempat budidaya dan peternakan kambing etawa. Sebagian besar penduduknya bekerja di sektor pertanian, peternakan, dan perkebunan. Telemung kini terus dikembangkan menjadi sebuah destinasi desa wisata dengan produknya berupa kopi. Desa Telemung tidak hanya menghasilkan kopi tetapi juga memiliki potensi lainnya seperti susu kambing etawa, gula semut dari mira kelapa, aren ( gula merah ) sampai peci dari anyaman bambu, hingga kini terus di kembangkan karena hampir produk dari Desa Telemung ini sudah tersebar sampai ke luar pulau. Berikut merupakan diagram yang menunjukkan komoditas terbesar di Desa Telemung yang pertama dalam sektor pertanian.

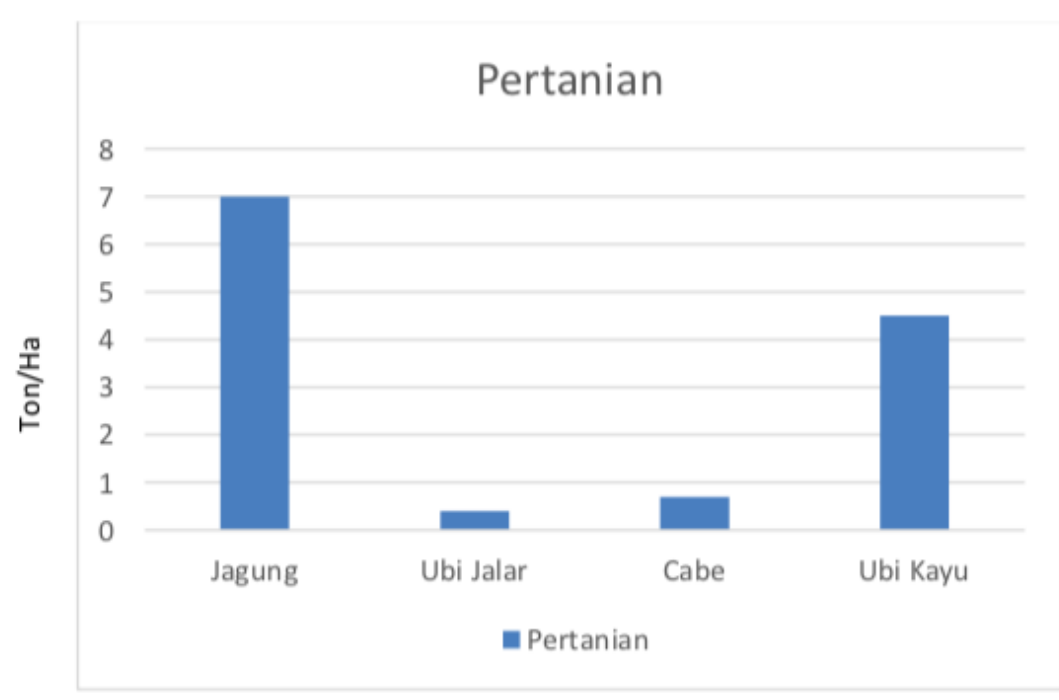

Gambar 1. Diagram Jumlah Komoditas Pertanian

Gambar 1 di atas menjelaskan bahwa jagung merupakan komoditi pertanian dengan hasil produksi tertinggi 7 ton/ha dan terendah yaitu ubi jalar sebesar 0,4 ton/ha. Diagram kedua merupakan diagram yang menunjukkan komoditas terbesar di Desa 
Telemung dalam sektor perkebunan yaitu sebagai berikut.

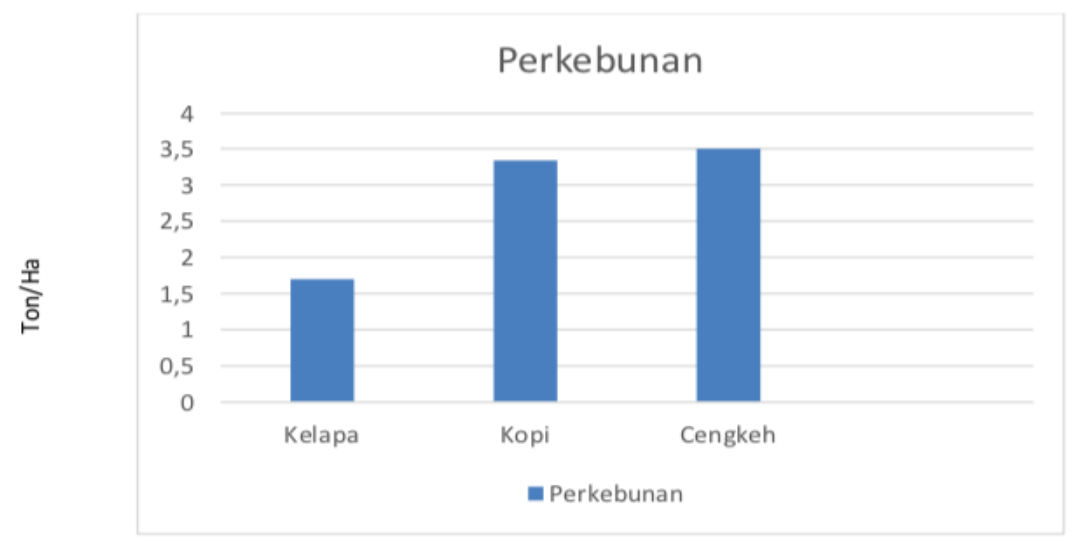

Gambar 2. Diagram Jumlah Komoditas Perkebunan

Gambar 2 memperlihatkan hasil perkebunan terbesar di Desa Telemung Kecamatan Kalipuro Kab. Banyuwangi dari diagram di atas yaitu kopi sebesar 3,34 ton/ha, cengkeh sebesar 3,075 ton/ha, dan terendah yaitu kelapa 1,7 ton/ha. Dan selajutnya, diagram ketiga menunjukkan komoditas terbesar di Desa Telemung dalam sektor peternakan sebagai berikut.

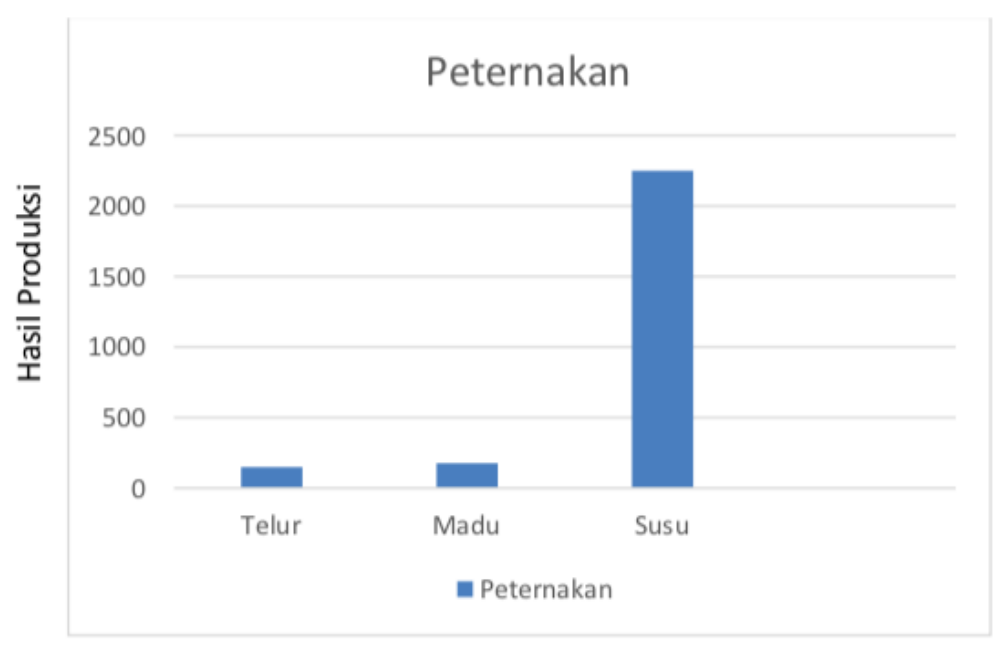

Gambar 3. Diagram Jumlah Komoditas Peternakan

Gambar 3 menggambarkan hasil peternakan terbesar secara berurutan di Desa Telemung Kec. Kalipuro Kab. Banyuwangi yaitu susu sebesar 2.251 L/Th, madu sebesar $175 \mathrm{~L} / \mathrm{Th}$ dan telur sebesar 150 buah/ th. Desa Telemung sendiri sudah memiliki Produk yang memiliki nilai jual yang bagus,baik dalam Pariwisata,Peternakan dan Pertanian. Berikut produk desa Telemung (Laporan Kegiatan KKN-Tematik, 2019).

\section{Solusi dan Target Luaran}

Berdasarkan mapping desa Telemung di atas, terdapat beberapa potensi komoditas desa yang dapat dikembangkan oleh stakeholder yang terlibat didalamnya. 
Dalam hal ini terdapat pengembangan potensi daerah dapat dilakukan dengan memaksimalkan kearifan lokan yang ada pada daerah tersebut. Terget luaran adalah meningkatkan potensi daerah melalui kearifan lokal dan komoditas yang tersedia pada desa Telemung dengan memaparkan ekplorasi dalam kegiatan.

\section{METODE PELAKSANAAN}

Kegiatan ini dilakukan dengan metode Focus Group Discussion, bersama dengan penduduk desa Telemung, Hasil diskusi menghasilkan beberapa mapping masalah dan solusi yang dipimpin langsung oleh Kepala Desa Telemung yaitu Misdi.

\section{Lokasi dan Waktu}

Kegiatan ini dilakukan di Desa Telemung, Kecamatan Kalipuro, Kabupaten Banyuwangi pada tanggal 1-14 Juli 2019.

\section{Peserta}

Diskusi atau Focus Group Discussion dilakukan dengan kelompok mahasiswa, staf ahli kebidangan, kelompok tani dan ternak, ibu-ibu PKK dan anggota administrasi pemerintahan desa. Dalam satu FGD dihadiri oleh 40 orang yang dilakukan dalam beberapa kegiatan.

\section{Metode Kegiatan}

Metode kegiatan merupakan peningkatan pemahaman terhadap suatu masalah. Banyak topic diskusi yang dilakukan, salah satu adalah mapping masalah dan solusi potensi desa yang dapat diangkat.

\section{HASIL DAN PEMBAHASAN}

Desa Telemung sendiri sudah memiliki Produk yang memiliki nilai jual yang bagus,baik dalam Pariwisata, Peternakan dan Pertanian. Berikut produk desa Telemung

\section{a. Omah Kopi Luwak}

Omah Kopi Luwak berada di Desa Telemung, Kabupaten Banyuwangi, Provinsi Jawa Timur, Indonesia Omah Kopi Luwak terletak di Desa Telemung yang merupakan kawasan lereng Pegunungan ljen di Kabupaten Banyuwangi, Provinsi Jawa Timur, Indonesia. Desa Telemung memiliki wilayah seluas $550 \mathrm{Ha}$ dan sebesar $330 \mathrm{Ha}$ didominasi oleh perkebunan kopi rakyat. Anda dapat mengunjungi lokasi ini dari pelabuhan Ketapang menggunakan bus jurusan Jember atau naik taxi ke arah kota, turun di perempatan Brak kemudian naik ojek ke Desa Telemung kurang lebih 15 menit, bila mengendarai taxi bisa langsung ke Desa Telemung. Jalur lainnya adalah via kereta api turun di Stasiun Karangasem atau Stasiun Banyuwangi Baru, kemudian naik taxi untuk bisa menuju ke desa Telemung. 


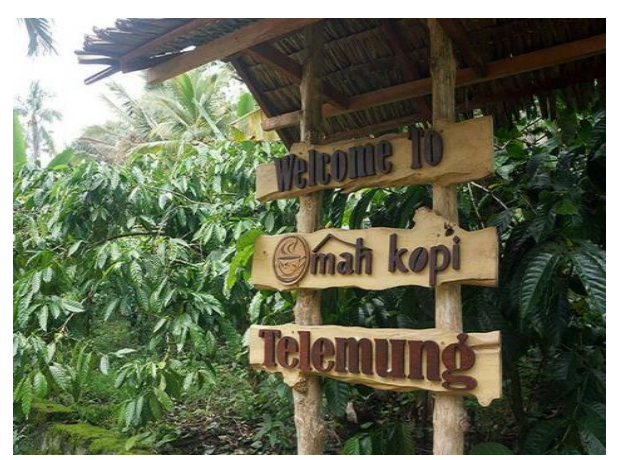

Gambar 4. Pintu Masuk Omah Kopi

Omah Kopi Luwak cocok untuk keluarga yang ingin berwisata, pecinta dan kolektor kopi Indonesia. Omah Kopi Luwak ditujukan untuk keluarga yang ingin mendapatkan pengalaman wisata berbeda setelah jenuh dengan aktivitas rutin. Omah Kopi Luwak juga ditujukan bagi para pecinta kopi yang rela menjelajah daerah-daerah untuk melengkapi koleksi kopi. Kami memiliki dua pilihan teknik pengolahan untuk menghasilkan karakter kopi berbeda. Pengolahan pertama dilakukan secara tradisional dan ditujukan bagi mereka yang gemar bertualang mencari citarasa kopi 'autentik' pengolahan kopi yang lainnya menggunakan mesin produksi sehingga para pecinta kopi dapat menikmati sajian kopi yang berkualitas dengan citarasa yang makasimal.

Para pengunjung dapat merasakan pengalaman ketika panen di bulan Juli hingga bulan Oktober. Selain di musim panen, pengunjung dapat ke omah kopi luwak di harihari biasa maupun di akhir pekan. Pengunjung yang datang ketika musim panen akan diberikan kesempatan untuk memetik buah kopi di perkebunan yang dikelola. Namun, para pengunjung diharapkan melakukan reservasi atau konfirmasi terlebih dahulu bila ingin datang ke omah kopi luwak, karena tempat wisata ini menjaga kulitas pendampingan setiap pengunjung yang datang.

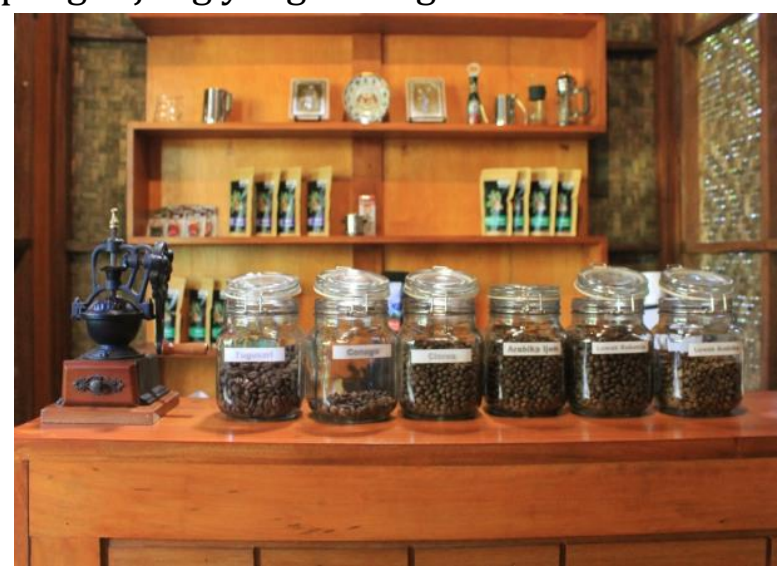

Gambar 5. Produk Omah Kopi

Pada gambar 5. menjelaskan tentang macam kopi di omah kopi yaitu Tugusari, conuga, cieres, arabika ijen, luwak robusta, luwak arabika. 


\section{b. Susu Kambing Etawa}

Susu Kambing Etawa merupakan salah satu produk ternak yang memiliki kandungan nutrisi yang tinggi. Menurut hasil dari penelitian yang dilakukan oleh United State Departement of Agriculture (USDA) menunjukkan gizi susu kakegumbing etawa mendekati komposisi sempurna ASI. Setiap 100 gram susu kambing mengandung 3-4\% protein, 4-7\% lemak, 4,5\% karbohidrat, 134 gram kalsium dan $111 \mathrm{~g}$ fosfor. Komposisi kimiawi susu kambing etawa mengandung protein, lemak, karbohidrat, kalori, kalsium, fosfor, magnesium, besi, natrium, kalium, vitamin A,B1 (IU), B2 (mg), B6, B12, C, D, E, Niacin, V, Asam Pantotenant, Kolin dan Inositol. Anak yang mengkomsumsi susu kambing memiliki kepadatan tulang yang baik, kadar hemoglobin meningkat, serta kecukupan vitamin A, B1, B2 dan B3 yang penting bagi pertumbuhan dan perkembangan sel otak dan saraf. Asam amino yang mengandung unsur belerang metionin, sistin dan sistein penting untuk membangun kesehatan otak dan sistem saraf, serta berperan dalam pembentukan sel darah penawar racun (detoksifikasi) bahan bahan kimia berbahaya yang masuk ke dalam tubuh.

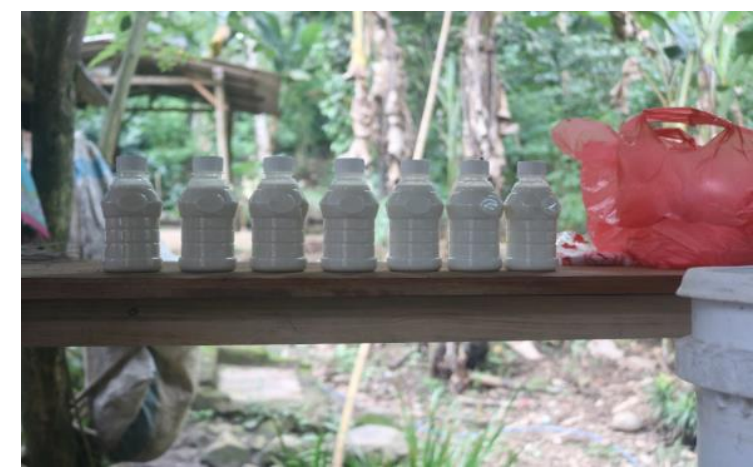

Gambar 6. Kemasan Susu Kambing Etawa

Walaupun pemanfaatan susu kambing masih kurang optimal disebabkan adanya anggapan bahwa susu kambing beraroma prengus seperti kambing sehingga kebanyakan orang kurang menyukainya. Oleh karena itu, dapat diolah menjadi susu pasteurisasi yang memiliki nilai jual tinggi dan menghilangkan aroma prengus pada susu kambing etawa tersebut.

\section{c. Permen Susu Kambing Etawa}

Permen susu merupakan produk pangan yang disukai semua orang mulai dari anak-anak hingga orang dewasa. Permen dapat menjadi peluang bisnis yang menguntungkan sehingga Desa Telemung dapat menciptakan inovasi baru dari susu kambing etawa dengan pembuatan permen yang sederhana.

\section{d. Gula Semut}

Desa Telemung memiliki potensi lain yaitu gula semut. Gula semut merupakan gula yang terbuat dari nira kelapa yang dapat digunakan sebagai bahan campuran kopi, teh, dan minuman lainnya. Gula semut dapat menjadi oleh-oleh untuk wisatawan yang berkunjung di Desa Telemung. Gula semut memiliki kandungan berupa Thiamin (Vitamin B1), Riboflavin (Vitamin B2), Nicotinic Acid (Vitamin B3), Pyridoksin (Vitamin B6), Ascorbic Acid, Kalsium. Manfaat gula semut yaitu mencegah anemia, menurunkan 
gula darah, menstabilkan kolesterol, meningkatkan daya tahan tubuh, melancarkan peredaran darah, mencegah asam urat, dan mengurangi risiko stroke.

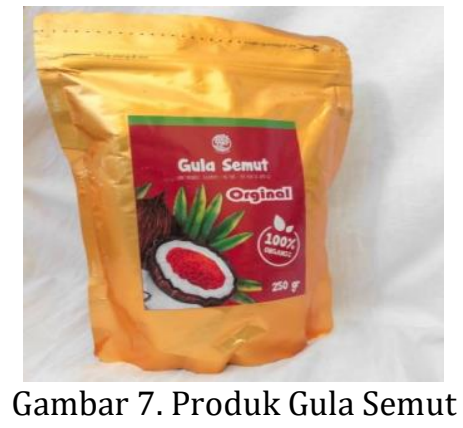

Gambar 7 menunjukan produk gula semut yang sudah menjadi produk dalam packing siap jual untuk konsumen. Produk ini juga sudah disiapkan untuk go-retail ke berbagai pusat oleh-oleh yang berada di Banyuwangi.

\section{Diskusi dengan Stakeholder di Desa Telemung}

Desa telemung memiliki kendala pada komoditinya salah satunya kopi. Kopi seperti cuaca saat musim hujan, penyelesaian yang ada yaitu memanen kopi dan menjualnya langsung. Selain itu juga adanya kendala internal pada slep keliling. Harga kopi yang terbilang cukup murah diakibatkan oleh kurangnya sumberdaya manusia yang termotivasi untuk mengembangkan komoditi yang ada seperti melakukan proses lanjutan sehingga dapat dipasarkan sendiri dan tidak melalui tengkulak. Untuk saat ini kopi dijual seharga 20.000 per-kilo sedangkan seharusnya kopi bisa dijual seharga 75.000 per-kilo dan 200.000 per-kilo jika menggunakan pupuk kendang. Utnuk mesin pengolahan sudah disediakan oleh pemerintah setempat namun tidak terealisasi karena SDM yang kurang motivasi untuk berkembang. Saat ini untuk pemasaran kopi melalui tengkulak dan untuk pemasaran susu melalu agen. Untuk peternak di Desa Telemung terdapat Sapi dan Kambing, hampir setiap peternakan yang ada di Desa Telemung memiliki Kambing dan hanya beberapa saja yang memiliki sapi. Dalam 1 RT di Desa Telemung terdapat 11 peternak Kambing, 7 peternak Sapi, dan hamper setiap ruman memiliki Ayam. Untuk perkebunan sendiri terdapat beberapa komoditi yang di tanam seperti kelapa, manggis, duren, pisang, kopi, alpukat dan langsat. Terkadang mereka menanamnya dalam satu kebun dan untuk sayuran belum ada warga yang menanamnya.

Selain permasalahan diatas pada kegiatan focus group discussions ditemukan beberapa permasalahan yang muncul dari warga Desa Telemung. Permasalahan pertama yaitu mengenai sumber daya manusia yang ketika diajak untuk mengembangkan lagi hasil-hasil pertanian dan peternakan mereka, namun terdapat penolakan dikarenakan proses yang terlampau tidak praktis dan lama mendapatkan keuntungannya. Mereka butuh bukti nyata terlebih dahulu keuntungan yang didapat sehingga mereka percaya dan ingin mengembangkan hasil-hasil pertanian dan peternakannya. 
Solusi yang ditawarkan dalam permasalahan pertama ini adalah menggunakan konsep pilot project. Apa itu pilot project? Adalah suatu pelaksanaan kegiatan percontohan yang dirancang sebagai pengujian trial dalam rangka untuk menunjukkan keefektifan suatu pelaksanaan program, mengetahui dampak pelaksanaan program, dan keekonomisannya.

Lalu bagaimana konsep pilot project dapat digunakan dalam membantu permasalahan pertama? Tentu, melihat sudah terbentuknya kelompok-kelompok tani di Desa Telemung, konsep pilot project sudah seharusnya dapat dengan mudah dilakukan. Kelompok tani menjadi pioner untuk melakukan pengembangan hasil-hasil pertanian dan peternakannya terlebih dahulu, lalu ketika keuntungan jauh melebihi keuntungan sebelum dikembangkan, para pioner langsung melakukan sosialisasi kepada warga Desa Telemung dengan menunjukkan bukti-bukti keuntungan tersebut.

Permasalahan kedua adalah mengenai wadah mereka untuk menjual hasil pertanian dan perkebunan. Sebenarnya, wadah untuk menjual sudah banyak. Para startup-startup e-commerce juga sudah mulai menjamur. Contoh wadah tersebut adalah TaniHub. TaniHub merupakan suatu platform e-commerce yang dirancang khusus untuk membantu para petani menjual hasil-hasil mereka sehingga para petani mendapatkan hasil yang adil. Hal ini digunakan untuk memaksimalkan branding dari suatu produk sebagai dasar strategi (Keller, Aperia, \& Georgson, 2008).

Jadi para petani seharusnya tidak kebingungan lagi untuk menjual hasil-hasilnya kemana. Karena di era industri 4.0, teknologi sangat berperan dalam membantu individu yang ingin berkembang, terutama petani. Lalu ada startup iGrow yang tujuannya membantu para petani yang punya lahan tapi tidak ada modal untuk dicarikan investor. iGrow merupakan platform yang membantu petani lokal, lahan yang belum optimal diberdayakan, dan para investor penanaman untuk menghasilkan produk pertanian yang berkualitas. Para petani yang kurang modal dan lahan dapat dengan mudah mendapatkan investor sehingga mereka tidak lagi sibuk mencari hutang untuk modal. Dengan adanya platform digital menyebabkan potensi digitalisasi pada industri (Martin \& Todorov, 2010)

Permasalahan ketiga adalah tengkulak. Seperti yang sudah dijelaskan pada solusi permasalahan kedua. Permasalahan mengenai tengkulak sudah bisa terselesaikan dengan mudah karena petani tidak lagi mengandalkan para tengkulak untuk menjual hasil pertanian dan peternakannya (karena ada TaniHub) atau melakukan kerjasama yang merugikan petani itu sendiri (solusinya adalah iGrow). Selain secara online adapun solusi yang dapat diberikan yaitu secara offline contohnya, menyatukan hasil panen atau komoditas dalam sentral penjualan berupa toko, pusat oleh-oleh dan lain-lain, pembentukan koperasi atau menggunakan dana BumDes sebagai modal petani untuk menghindari tengkulak, dan melakukan branding pada komoditas agar barang mempunyai value added (Kapferer, 2008).

\section{SIMPULAN}

Potensi lokal yang berupa komoditas merupakan keunggulan yang harus dapat dimaksimalkan. Seperti halnya produk jadi, komoditas harus mempunyai value added 
yang tinggi sehingga mempunyai nilai jual yang tinggi pula. Kemudian dengan adanya digitalisasi di berbagai sektor, hal ini harus dimanfaatkan dengan menerapkan pengelolaan komoditas secara digital dari hulu hingga hilir. Partisipasi seluruh stakeholder sangatlah penting untuk kelangsungan peningkatan potensi daerah yang terus berkembang dan berkisinambungan.

\section{DAFTAR RUJUKAN}

\section{http://telemung.desa.id/web/detailnews/kondisi-desa}

Kapferer, J.-N. (2008). The new strategic brand management. London: Kogan Page.

Keller, K. L., Aperia, T., \& Georgson, M. (2008). Strategic brand management. Harlow, England: FT Prentice Hall

Laporan Kegiatan KKN-Tematik. (2019). Pengembangan Usaha Susu Kambing Etawa di Desa Telemung, Kecamatan Kalipuro, Kabupaten Banyuwangi. UPN “Veteran” Jawa Timur.

Martin, M. \& Todorov, I. (2010). How will digital platforms be harnessed in 2010, and how will they change the way people interact with brands? Journal of Interactive Advertising. Journal of Marketing Management. 10(2), 61-66. 
130 J-Abdipamas, Vol. 3, No. 2 Oktober, 2019 